\title{
Market potential, productivity and foreign direct investment: Some evidence from three case studies
}

First version: April 2008

This version: January 2009

\author{
Lionel Artige \\ HEC - Université de Liège \\ Economics Department \\ Bd. du Rectorat 7 - Bât. B31 \\ 4000 Liège \\ Ph. +3243664891 \\ e-mail: lionel.artige@ulg.ac.be

\section{Rosella Nicolini} \\ (Corresponding author) \\ Instituto de Análisis Económico - CSIC \\ Campus de la Universitat Autònoma de Barcelona \\ 08193 Bellaterra (Barcelona) \\ Ph. +34 935806612 \\ e-mail: rosella.nicolini@iae.csic.es
}

\begin{abstract}
This paper aims at analysing the importance of local determinants to foreign direct investment (FDI) in three European regional case studies. The originality of the approach lies in the use of disaggregated data by sector and by region. The results are threefold. First, regional demand and productivity are fundamental FDI determinants, confirming most studies with national data. Second, regional FDI inflows are more dependent on regional than national determinants. Finally, the effect of market potential measured with absolute GDP on regional FDI diminishes linearly with distance and does not when measured with GDP per capita.
\end{abstract}

Keywords: Foreign Direct Investment, Market Potential, Productivity, Regions.

JEL: F20, O18, R10. 


\section{Introduction}

Foreign direct investment ${ }^{1}$ (FDI) flows in the world have grown rapidly since the 1990 s, more rapidly than trade flows between countries. They accounted for approximately 1 per cent of the world GDP before 1995 and between 2 and 4 per cent thereafter. ${ }^{2}$ Local and national governments all over the world compete strongly to attract FDI as it is widely considered that FDI provides jobs, productivity and stable capital flows. However, the main determinants guaranteeing the inflow of foreign capital are still heatedly debated in the economic literature (Barba Navaretti and Venables 2004). Many determinants have been tested at the national level in the empirical literature but the results have often been ambiguous (see Section 2). From an empirical point of view, since foreign investment is concentrated on a few locations, regional and sectoral data should yield more precise estimations than national averages. Moreover, from a policy point of view, regional analyses should be helpful in evaluating the usefulness and the targets of regional public spending devoted to attracting FDI.

The purpose of this paper is to investigate the FDI determinants by using disaggregated data both at sector and regional levels. We present three case studies in which we test the effect of market size, productivity, export intensity and market potential on FDI inflows. The research questions are threefold: what is the effect of these determinants on regional FDI? Is regional FDI more dependent on regional than national determinants? Does the effect of market potential on regional FDI diminish linearly with distance?

We selected three European regions defined by the European NUTS1 and NUTS2 classifications, for which we obtained comparable data: Baden-Württemberg (Germany), Catalunya

\footnotetext{
${ }^{1}$ Foreign direct investment is the capital transaction that a "direct investor" carries out in a foreign "direct investment enterprise" (affiliate) to obtain a lasting interest in this foreign firm and a significant degree of influence on its management. The threshold of $10 \%$ - or more - ownership of a firm's capital is in general required to be accounted for as a direct investment. Cross-border mergers and acquisitions have been a growing component of FDI flows in the recent past.

${ }^{2}$ See UNCTAD database: www.unctad.org.
} 
(Spain) and Lombardia (Italy). ${ }^{3}$ We built a panel using comparable data on FDI at regional and industry levels and potential determinants at national, regional and sector levels over the period 19952005. Apart from data availability, there are other interesting features shared by these regions. They do not have a capital city and have close corporate tax rates $(\sim 35 \%),{ }^{4}$ which rules out tax competition as an FDI determinant. In addition, they belong to the Euro-zone, where many trade frictions have been eliminated. Thus, the number of potential discriminating FDI determinants among them is reduced, which is desirable due to the limited size of our sample.

The results of the paper show first that regional market size, market potential and unit labour costs are important determinants of the inflows of FDI in the three regions. As for market size, this result at the regional level confirms most of the studies carried out with national data. Second, regional FDI inflows are more dependent on regional rather than national determinants, suggesting that foreign firms are sensitive to what local markets can offer. Third, the effect of market potential measured with GDP on regional FDI diminishes linearly with distance, as claimed by the economic geography literature, but does not when the market potential is measured with GDP per capita.

The paper proceeds as follows. In Section 2, we provide a brief literature review. Section 3 tackles the issue of proximity of markets for firms. In Section 4, we propose some descriptive statistics on FDI and its potential determinants in the three regions. We present the results of the empirical analysis in Section 5 and the conclusions in Section 6.

\footnotetext{
${ }^{3}$ Our exercise is limited to a sample of regions belonging to the European Union that are experiencing a European market integration process. The results should be interpreted by making reference to this specific context.

${ }^{4}$ Source: www.taxpolicycenter.org.
} 


\section{Literature review}

General equilibrium models typically distinguish two main motivations for a firm to make direct investments in foreign countries (Markusen 1984, Helpman 1984). The first one is to avoid trade frictions (tariffs, transport costs ...) to serve the local market better. This type of FDI is called "horizontal" or "market-seeking" since it implies a duplication of production plants. The second motivation is to have access to lower-cost inputs. This type of FDI is called "vertical" or "production cost-minimizing" since there is fragmentation. The objective is to economize on production factors to maximize profits on each part of the production line. In a general equilibrium "knowledge-capital model", Markusen (1997) integrates the horizontal and vertical motivations of FDI decisions.

Due to the difficulty in building tractable general equilibrium models, the large body of empirical literature on FDI determinants is based on partial equilibrium frameworks and tests various determinants of FDI decisions. The data used are generally at industry level or at country level and, when they are available, at firm and plant level. ${ }^{5}$ Measured by GDP or GDP per capita, market size seems to be the most robust FDI determinant (e.g. among many others, Kravis and Lipsey 1982, Wheeler and Mody 1992, Billington 1999). Other determinants are more controversial. Labour cost is found to be positively related to FDI by Wheeler and Mody (1992) and Feenstra and Hanson (1997). The effect is negative for Culem (1988) and insignificant for Lucas (1993). The effect of taxes on FDI has been the subject of many papers, with contradictory results (see Billington 1999 or Markusen 1997, 2002). Another potential determinant of FDI is the agglomeration of economic activities emphasized by the new economic geography literature. Firms are attracted to a few locations where they can find high-quality infrastructure and human capital, large demand, knowledge externalities but also tough competition. Wheeler and Mody (1992) found that these agglomeration effects are positive and highly significant for US FDI, as well as Redding and Venables (2004), Head and Mayer (2004b) and Hanson (2005). Their conclusions are based on the use of a function of market potential inherited

\footnotetext{
${ }^{5}$ For an extensive review of this literature, see Caves (1996), Chakrabarti (2001) and Blonigen (2005).
} 
from geographers (Harris 1954). Harris's market potential function is a measure of demand potential around a particular location weighted by transport costs. In its modern versions, this function includes profitability and productivity potential measures of a location and its neighbouring area. Using this approach, Crozet, Mayer and Mucchielli (2004) show that Paris and the regions near the frontiers are major recipients of FDI by using plant-level data for the 92 French departments. The effects of market size and agglomeration are positive while they are negative for wages at plant level. Boudier-Bensebaa (2005), using aggregate FDI data at county level for Hungary, finds that unemployment rate, local market size and agglomeration effects have a positive and significant effect on FDI location. As discussed in Bloningen et al. (2007), the positive association of market size and agglomeration with FDI inflow is related to spatial proximity and demand access. Head and Mayer (2004b) examine the effect of market potential using measures that include not only the host region's GDP, but also that of adjacent regions. They test the robustness of their results with a few alternative measures.

\section{The importance of proximity}

A foreign firm may decide to make an investment in a specific foreign location in order to supply at the lowest cost a national market or even foreign markets around this location. Many empirical studies on firms' location show that firms locate as close as possible to consumers (Blonigen 1999 and 2005). Bloningen (2005) and Bloningen et al. (2007) discuss the issue that FDI in developed countries is mostly horizontal, for which the motivation is market access. According to Feenstra (2004) among others, horizontal FDI occurs if a firm chooses to produce in different countries with each plant selling locally to a market. Markusen (2002) argues that there are two factors that turn out to be crucial to the existence of horizontal FDI: the size of the local markets and the marginal production cost in the case of producing directly in the host market. As for the first factor, since firms invest abroad to serve the local host market, the size of the local demand will be the determinant for the firm's investment decision. The second factor, the level of local production costs, will determine whether the firm 
produces locally to sell locally or whether it supplies the host market by exporting its home-based production.

Feenstra (2004) and Markusen (2002) develop a simple theoretical framework based on a monopolistic competition setting describing how firms decide whether to export or make a horizontal foreign investment. If a firm exports from region $i$ to region $j$, it incurs an iceberg transport cost, whereas if it decides to make a foreign investment, it incurs a plant-specific fixed cost. However, for the investment to be considered as a horizontal FDI, it is necessary that a firm in region $j$ finds it more profitable to open a plant in region $i$ than to export there. According to this framework, FDI will be more likely when transport costs are high, plant fixed costs low and labour productivity high. We should therefore expect on FDI inflows a positive effect of market demand (weighted by distance) and labour productivity. It should be noted that modelling transport costs as iceberg transport costs provides tractability to models and creates heterogeneous spatial market areas for production. The empirical results obtained with this modelling approach of transport costs must be analysed with caution since iceberg transport costs capture a particular price differentiation associated with distance. As argued in McCann (2005) and Dewhurst and McCann (2007), transport costs are also influenced by other effects such as the per-quantity tariff applied to the delivering prices. ${ }^{6}$

Finally, another geographic dimension of a framework à la Feenstra and Markusen is the importance of the vertical and horizontal linkages a foreign firm is able to establish with the local producers. The potential synergies stemming from these relationships reinforce the location advantages of a specific territorial unit. These mechanisms are known as specialization effects (horizontal linkages) and diversity effects (vertical linkages), as discussed in Rosenthal and Strange (2004). These potential effects justify the use of dummies to capture them in territorial units.

\footnotetext{
${ }^{6}$ Transport costs may exhibit economies of scale for any distance as the quantity to be delivered (over any distance) increases and the transport cost per unit of quantity falls.
} 


\section{Descriptive statistics}

The regions of our sample have one of the highest GDP per capita within their respective countries without possessing the traditional attributes that come with central political power. Nevertheless, there are some differences among them, making each of them an interesting case study. Baden-Württemberg and Lombardia are significantly more populated than Catalunya (see Table 1). They are also wealthier. Baden-Württemberg is the richest of the three regions as measured by an indicator of GDP per capita in $2005 .^{7}$ All the regions have very open economies with a high level of exports as a percentage of GDP (almost $30 \%$ on average) (Figure 1).

\section{[Table 1 about here]}

[Figure 1 about here]

In our sample of regions, the performance of FDI inflows is the highest in Baden-Württemberg and the lowest in Catalunya. The analysis of cumulative flows by sector reveals a few common trends and peculiarities, which provide information on the economic landscape of each region (Table 2 and 3). The Finance and Credit sector accounts for a large share of FDI inflows in all the regions, though to a lesser extent in Lombardia (17\%). The cumulative FDI flows in Catalunya are dominated by two sectors, Finance and Credit and Other Services, which accounted for $70 \%$ of FDI inflows and about $50 \%$ of FDI outflows over the period 1993-2003. In Baden-Württemberg, more than $70 \%$ of cumulative FDI inflows are realized by financial institutions. This means that firms entering this market are, to a wide extent, banks and the investment operations are mostly acquisitions of domestic firms' shares.

The distribution of cumulative FDI outflows is more balanced. The firms from this German region investing abroad belong to the sectors of Finance and Credit, Other Services, Traditional Manufacturing and Machinery and Automotive. In Lombardia, the distribution of cumulative FDI

\footnotetext{
${ }^{7}$ Source: Eurostat database.
} 
inflows reveals more diversified foreign investment and a predominance of manufacturing investments: $31 \%$ in Traditional Manufacturing, $16 \%$ in Machinery and Automotive, $10 \%$ in the electrical, electronic and high-tech industries and 9\% in Chemical. The sector of Other Services does not represent a high share of cumulative FDI inflows and outflows. This shows the high specialization of this region in industry. The Lombardian banks are nonetheless active abroad. The sector of Finance and Credit accounts for 34\% of cumulative FDI outflows. Finally, the statistics in Table 4 indicate that most of the FDI inflows of our sample originate from the European Union.

[Table 2 about here]

[Table 3 about here]

[Table 4 about here]

\subsection{The demand size}

Two indicators of demand size are considered: market size and market potential. Market size measured by absolute GDP or GDP per capita is an indicator of the demand potential of a specific unit of space a region or a country, for instance (Head and Mayer 2004a). Market size is also an indicator of the existence of potential economies of scale. GDP per capita reflects the level of purchasing power while absolute GDP the size of the economy. ${ }^{8}$

The access for a firm to the demand of a region or a country is not uniform across space. Harris (1954) found that demand is higher in the areas where production is located. Owing to gravity theory, he concluded that production was more likely to settle in regions that guarantee the largest market access. ${ }^{9}$ The market potential indicator, by weighting absolute GDP or GDP per capita by distance,

\footnotetext{
${ }^{8}$ Absolute GDP can be a misleading measure in developing countries. A large but poor economy can yield a very low demand for certain industries (Chakrabarti 2001). It is then justified to complement the analysis with GDP per capita. Nevertheless, it can also be interesting to associate both indicators in studies on developed countries.

${ }^{9}$ We are implicitly assuming that firms incur a transport cost to deliver their goods or services.
} 
provides a measure of this market access for firms. Harris (1954) proposed the following indicator to compute the market potential $(M)$ of region $i$ relative to the relevant set of other $J$ regions:

$$
M_{i, J}=\sum_{J} \frac{Y_{j}}{d_{i, j}}, \quad j \in J,
$$

where $i$ is the home region, $j$ a region or a country, Y stands for GDP per capita of a region or a country and $d$ is the bilateral distance between the locations $i$ and $j$. Thus, the market potential of a location (namely a region) is measured by the sum of GDP per capita of surrounding locations (namely regions or countries) weighted by the bilateral distance between each of the latter and the former. We build two indicators of market potential to proxy the demand potential in the immediate vicinity of and farther away from the regions (Combes, Mayer and Thisse 2006). The first indicator, market potential of neighbouring regions, measures, for each of the three regions, the market potential of the surrounding regions (NUTS2 regions for EU regions and cantons for Swiss regions). ${ }^{10}$ The bilateral distance between each of the surrounding regions and the home region (considered as a centroid of this basin of attraction) is the number of road kilometres between their regional capital cities. ${ }^{11}$ The second indicator, market potential of neighbouring countries, measures, for each of the three regions, the market potential of the surrounding countries. Figures (2) and (3) show the values of these two indicators for the three regions between 1995 and 2005. There is a lot of disparity between regions for the market potential of neighbouring regions while the variance of market potential of neighbouring countries is much smaller.

[Figures 2 and 3 about here]

\footnotetext{
${ }^{10}$ The composition of the surrounding regions and countries for each home region is given in the Appendix.

${ }^{11}$ We compute these by using the Guide Michelin website (http://www.viamichelin.es/viamichelin/esp/tpl/hme/MaHomePage.htm).
} 


\subsection{Unit labour cost}

Unit labour cost is one of the indicators to assess labour productivity. It is calculated by dividing the average compensation of employees (wages plus benefits) by nominal added value. Therefore, this indicator ranges from 0 to 1 . The lower the indicator, the higher the productivity. We computed the unit labour cost for two sectors (industry and services) that are the most relevant for FDI flows, over a period (1995-2004) for which data are available. In the first graph, we present the unit labour cost in industry in the three regions (Figure 4). Two regions (Catalunya and Lombardia) have relatively similar performance. The Lombardian unit labour cost in industry is quite low (i.e. high productivity) while those of Baden-Württemberg and Catalunya are relatively high. In the sector of services, the variance of performance is lower and the unit labour cost level is lower than in industry (Figure 5). In 1995, Baden-Württemberg had the lowest level of unit labour cost, but there is deterioration over the time period while there is an improvement in Lombardia. It is in Catalunya that the level of unit labour cost is the highest and remains so over the time period.

[Figures 4 and 5 about here]

\section{Empirical analysis}

In this section, we test the effect of a few determinants on FDI inflows. The objective is to answer the three following questions: what is the effect of these determinants on regional FDI? Is regional FDI more dependent on regional than national determinants? Does the effect of market potential on regional FDI diminish linearly with distance?

We built a database focusing on FDI inflows at the regional and sectoral levels and its determinants at the national, regional and sectoral levels. We collected data from various regional statistical offices $^{12}$ and from Eurostat for the period 1995-2005. At the moment, there is no complete

\footnotetext{
${ }^{12}$ Lombardia: Ufficio Italiano Cambi and Annuario Statistico Lombardia, Catalunya: IDESCAT and Secretaría General del Comercio Exterior, and Baden-Württemberg: Statistiches Landesamt Baden-Württemberg.
} 
and reliable information at the regional level before 1995, the year when Eurostat initiated the collection of data at the regional level. Once the data by year and region had been collected, we worked out the database to order it in six comparable sectors at the regional level. We labelled the sectors as follows: Traditional manufacturing (including food and beverage, textile, paper, metal products, wood furniture), Mechanical, Machinery and automotive, Electrical, electronic and hightech, Chemical, Financial and business services (including holdings) and Other services.

For every year, we have data corresponding to the 6 selected sectors and we organize them in such a way as to merge sectors and years. For each variable, we build a vector as a list of the 10 years and for each year we list the 6 sectors. For Baden-Württemberg and Catalunya, we have a final matrix of 60 observations.As for Lombardia, we reduce the sample to 36 observations since data were not available for the entire period. ${ }^{13}$ The sample period starts from 1997 and ends in 2003.

For each region, the general equation for our estimation is the following:

$$
\left.F D I p_{i j}=\alpha_{j}+\underline{\beta x_{i j}}+\varepsilon_{i j}, \quad j(\text { sectors })=1 . .6 \text { and } i \text { (years }\right)=1995 \ldots . .2002
$$

where FDIp $i j$ represents the annual per-capita inflows of FDI in each region and $\beta x_{i j}$ is a vector of variables selected as proxies for FDI determinants. We follow the literature to select the potential FDI determinants. We isolate regional GDP per capita and market potential as a proxy for regional demand, and exportation for openness to trade. Moreover, we test an indicator of labour productivity, unit labour cost (compensation of employees per unit of value added).

One should reasonably expect that all these factors but one display a positive correlation with the amount of FDI inflows. They proxy the local factors that investors are likely to look for when they decide to invest. The only one that is expected to show a negative coefficient is unit labour cost since an increase in this indicator means a decrease in productivity and hence a less attractive determinant for investors. In addition, we introduce dummies by sector to enquire whether FDI inflows by sector

\footnotetext{
${ }^{13}$ The office in charge of collecting these data (Ufficio Italiano Cambi) no longer exists and has not yet been replaced.
} 
are attracted by the specialization of a region in one specific sector or, on the contrary, by the economic diversity (cross-sector externalities) of that region. ${ }^{14}$ We apply the cross-section technique to each regional matrix at two dimensions (by year and by sector). We run regressions by estimating the matrix with the OLS technique (including fixed effects) and applying the White correction for controlling for heteroskedasticity problems. ${ }^{15}$ The variables selected for each region $i$ and sector $j$ annually are summarized in Box 1. In addition, to control for size effects, we normalize to population all variables. This means that we analyse the determinants of per-capita FDI inflows in each of our three regions. We also allow two measures of market potential to capture the wealth (using GDP per capita) and size effects (using GDP) in order to analyse the interplay between these two effects and the spatial dimension. Finally, in order to control for the potential endogeneity problem associated with simultaneity between the dependent and the independent variables, we run all the regressions using lagged regressors.

[Box 1 about here]

\subsection{Pooled sample}

We start by pooling all the data of the three regions to check whether regional idiosyncrasies exist. If so, estimations region by region would thus be relevant. We run a few regressions in order to determine the statistical significance of the determinants we selected. It has not been possible to run a unique regression including all the variables at once because of multicollinearity problems among some of them. ${ }^{16}$ In order to test the existence of regional idiosyncrasies, we introduce into the pooled

\footnotetext{
${ }^{14}$ On specialization versus diversity, see Rosenthal and Strange (2004).

${ }^{15}$ This is the most suitable way to proceed for this kind of exercise, as discussed in Greene (2000) and Wooldridge (2002).

16 We do not have a sufficient number of variables to run instrumental variables (IV) estimations.
} 
estimation fixed effects by regions. Table 5 reports the most relevant results, including the F-test that assesses the importance of regional idiosyncrasies. ${ }^{17}$ Our specifications confirm that regional fixed effects matter (LSDV ${ }^{18}$ estimators). ${ }^{19}$

[Table 5 about here]

\subsection{Regressions by region}

Having tested for the regional idiosyncrasies, we proceed to the estimations of FDI determinants for each region separately. As in the pooled sample, we begin by considering a common specification regression for all our regions, including the group of the variables listed in Table 5 except for the variables with high collinearity. We present them in Table 6. In these alternative specifications, we control for heteroskedasticity and multicollinearity effects.

\section{[Table 6 about here]}

Table 6 summarizes the empirical results obtained for each region: Catalunya, Baden-Württemberg and Lombardia. We regress FDIP (foreign direct investment per capita by region and by sector) on a few determinants including GDP per capita ${ }^{20}$ and regional productivity measures at sector level. ${ }^{21}$ In the case of Catalunya, we also take into account the diversion effect of FDI within the European Union associated with the accession of Central and Eastern European countries. As the report by the

\footnotetext{
${ }^{17}$ The results of the estimations without regional fixed effects are available upon request.

${ }^{18}$ LSDV stands for Least Square Dummy Variable.

${ }^{19}$ Including fixed effects means that latent regional variables exist that deserve to be considered but the data at hand prevent us from identifying them. Egger (2008) argues that legal, cultural and institutional elements are unobserved factors that can be easily taken into account by applying a fixed effect method.

${ }^{20}$ FDI inflows' fluctuations in a region may reflect booms and busts of the global economy (for instance, economic crises). By including a measure of regional GDP changing over time, we partially consider the effects of these world fluctuations.

21 There are other factors influencing the attractiveness of FDI toward a specific location, for instance, local institutions, property rights, the environmental policy, fiscal and financial schemes, corruption and bureaucracy as well as the stability of the exchange rate. All these factors may improve or deteriorate the local environment, which may affect FDI inflows (see Bloningen 1997, Hanson 2001, Frederiksson 2003 and Gorg et al. 2009). However, we do not include these factors in our analysis because there are no data or reliable information for our regions.
} 
European Policy Research Centre et al. (2000) shows, Catalunya now has to compete with these new Member States to attract FDI. We therefore include two dummy variables for 2003 and 2004 corresponding to the years for which this effect is likely to happen in our sample period. ${ }^{22}$

Looking at the results across regions, a few comments can be made. First, GDP per capita by region is statistically significant for our sample of regions. Market size is thus an important and statistically significant FDI determinant. This confirms the findings of previous works on FDI at the national and regional levels. Moreover, this result provides further evidence of the horizontal nature of FDI in these three regions, where market size predominates as a determinant. Second, labour productivity measured by unit labour cost is statistically significant and has the expected negative sign for all three regions. Third, in each specification, we introduce a dummy associated with the distribution by sector of the FDI inflows to capture the specialization or diversity effects at the regional level. These dummies are always significant. The dummy DUM reflects the high share of manufacturing in the FDI distribution in Lombardia, while the dummy DAVERAGE gives higher weight to the sectors that receive a high proportion of FDI (namely more than the annual average) in Catalunya and Baden-Württemberg. In the latter two regions, FDI inflows do not target a unique sector all the time, but they alternately flow to different sectors. This suggests that the structural diversity of these regional economies possibly generates cross-sector externalities, which may be attractive for FDI going to these regions. In Lombardia, the DUM dummy is positive and statistically significant, implying that the specialization in manufacturing is a strong and permanent determinant of FDI inflows in this region. The statistically significant dummies and fixed effects in the three regions mean that heterogeneity by sector is an important component of our analysis. By heterogeneity, we mean the characteristics related to each sector: for instance, risk, entrepreneurial ability (as in Henderson 2003) and also asymmetric supply or demand shocks that can affect regional economic activity. Moreover, in this way, we control for the specialization and diversity effects associated with the regional economic

${ }^{22}$ Catalunya, like other regions (Scotland, for instance), has experienced the diversion effect due to the enlargement process of the European Union. Catalunya has always attracted labour-intensive foreign investments (because of low wages) and now faces the competition of the new Member States within the European Union. 
environment. In the case of Catalunya, the diversion dummies (D2003 and D2004) are always significant, suggesting that the diversion effect may have had an impact on Catalunyan FDI inflows.

The regional export performance variable (EXPORTP) is significant and positive in all the regions except Lombardia, where the coefficient is close to zero. The relationship between foreign investments and export performance in Catalunya and Baden-Württemberg may indicate that these foreign investments have contributed to the export performance, or the increasing export performance has been a good signal in terms of competitiveness for foreign investors to favour those destinations.

\subsection{The role of the demand potential}

Regional market size, measured by GDP per capita at the regional level, turns out to be, from our results, an important FDI determinant for all the sample's regions. Yet, as discussed in Section 2, it could be argued that the location decision of foreign investment is eventually driven by the access to other markets that this location offers rather than by its market size per se. To assess the potential effects of agglomeration or market access on regional FDI inflows, we use a measure of national market size (GDP per capita at the national level) and two indicators of market potential to proxy the demand in the immediate vicinity of and farther away from the regions. Our indicators of market potential are based on Harris (1954), as described in Section 3. We compute them by using GDP per capita (at the regional and national levels) and we repeat the same exercise with absolute GDP (at the regional and national levels). The results are presented in Table 10. The former indicator of market potential captures the consumers' level of wealth in the surrounding markets, while the latter measures the size effect of the market associated with the (national or regional) surrounding markets. The national GDP per capita and both indicators of market potential (by region and by country) can be introduced as independent variables in our estimations. The objective is, on the one hand, to test the relationship between regional FDI inflows and each of these demand variables, and, on the other hand, compare the magnitude of their coefficients if these variables are statistically significant. Tables 7-9 
report the regressions of regional FDI inflows per capita and by sector alternately on the four spatial measures of demand potential per capita. All these specifications appear to be robust. All the determinants are always statistically significant with the expected sign. The indicators of labour productivity keep a constant coefficient in Lombardia and Catalunya, while they vary a little in BadenWürttemberg. The regional dimension seems to add stability to all the variables, in particular labour productivity, which yields more contradictory results in studies at the national level. In all three regions, both variables for market potential are positive and statistically significant, implying that FDI in these regions is mostly horizontal (as discussed in Bloningen et al. 2007). Moreover, the ranking of the coefficient values is exactly the same for all the regions. The highest coefficient is found for regional GDP per capita and the lowest for national GDP per capita while, for the market potential variables, the coefficient is higher for the market potential of the surrounding countries than that for the surrounding regions. Foreign firms' location decisions appear to be motivated by the demand in the location (region) per se and, to a lesser extent, by the demand in the surrounding countries. This result tends to show that the effect of demand potential measured by using GDP per capita on regional FDI does not diminish linearly with distance. We repeat this exercise using absolute GDP instead of GDP per capita. As already mentioned, market demand can also be measured by absolute GDP (Table 10). GDP per capita captures the consumers' level of wealth in the area while absolute GDP captures potential scale effects of the area's market size. The results with absolute GDP show that all the regressors keep the expected sign, and the coefficients for unit labour cost and the dummies remain roughly the same. However, looking at our four demand potential variables, the results differ from the previous exercise. The coefficient of the market potential by region is larger than that by country, which is the opposite result to that found with GDP per capita. Therefore, the effect of demand potential measured by using absolute GDP on regional FDI diminishes linearly with distance. The difference in the results seems to show that the size of local demand is important for foreign investment. This is in line with the economic geography literature, which claims that local size effect 
is a centripetal or attracting factor (Fujita et al. 1999). This outcome may be explained by the fact that the interaction between the size and wealth effects with distance does not preserve the linearity of the distribution of the FDI flows across space. This result is interesting in the wake of the findings of McCann (2005) and Fingleton et al. (2007): empirically, the existence of economies of distance makes the price structure associated with transport costs not fully convex in distance.

\section{Conclusion}

In this study, we examine the potential determinants likely to attract FDI in three European regions. In the first part, we provide an overview of the FDI trends by sector and by region possibly associated with a selection of potential determinants. The choice of concentrating on the regional dimension is driven by the hypothesis that FDI hosted by regions may rely on local determinants. We run regressions to identify a relationship between regional FDI inflows by region and by sector and those determinants. The estimations by regions aim to identify possible regional idiosyncrasies. The test run for the pooled sample confirms their existence.

Our results show that, in line with the empirical literature on the subject at the national level, there is always a positive and statistically significant relationship between market size and regional FDI per capita in our sample of regions. The regional level of productivity measured by the unit labour cost also appears to be an important determinant of regional FDI. The importance of local determinants is reinforced by the second result of this paper: regional FDI inflows turn out to be more dependent on regional rather than national determinants. The foreign firms that invested in these three regions may have done so after considering the strengths of the local business climate, imperfectly represented here by market size and labour productivity. This location choice can be perfectly compatible with the objective of targeting markets beyond the regional market. This is exactly what our estimations show with the market potential of the surrounding areas of the three regions. When we use absolute GDP to construct the market potential indicator, the relationship between market potential and regional FDI is stronger for the surrounding regions than the surrounding countries. This result is 
in line with the claim of economic geography that market potential diminishes linearly with distance. However, we obtained the opposite result when we considered market potential built with GDP per capita, the level of wealth of consumers.

The results obtained with these three European case studies tend to validate the relevance of regional policy towards foreign investment in Europe. Even though regional economic strengths and weaknesses are often purely market outcomes, regional public spending and legislation can affect these FDI determinants. For instance, regional policy can improve infrastructure, transport and communication networks. The improvement of public infrastructure may contribute to reducing the distance effect for production delivery and workers' commuting, hence may increase local competition and market size. Such a regional policy should result in augmenting both local market potential and local productivity, and thus have an effect on FDI. Local taxation and subsidies can also be an issue for foreign firms. Many countries have adopted fiscal schemes to attract FDI. The results of our paper tend to argue in favour of such policies designed at the regional level. However, tax exemptions and subsidies should be coupled with other regional policies (infrastructure, training of the workforce ...) to guarantee long-term foreign investment and avoid low tax and high subsidy shopping.

The present paper focuses on regional case studies in Europe and does not claim to draw conclusions for regions outside Europe. In addition, even in Europe, the available data on regional FDI are extremely limited, which prevented us from carrying out a more reliable statistical exercise. Nevertheless, our preliminary results make us think that the possible relevance of the regional level to studying FDI determinants deserves to be further explored as soon as more data are available in Europe and elsewhere.

\section{Acknowledgements:}

We are grateful to the Editor, Ph. Cooke, two anonymous referees, Isabel Busom, Rosina Moreno for useful suggestions. We thank IDESCAT, Istituto per il Commercio Estero, Secretaría General del Comercio Exterior, Statistiches Landesamt 
Baden- Württemberg and Ufficio Italiano Cambi for data they provided. Any remaining error is our responsibility. Rosella Nicolini's research is supported by a Ramón y Cajal contract. Financial support from grants 2005SRG00470 and SEJ200501427/ECON is acknowledged.

\author{
[Table 7 about here] \\ [Table 8 about here] \\ [Table 9 about here] \\ [Table 10 about here]
}

\title{
6. List of References
}

Barba Navaretti, G. and A. Venables (2004) Multinational Firms in the World Economy, Princeton Unviersitity Press.

Billington, N. (1999) “The Location of Foreign Direct Investment: An Empirical Analysis”, Applied Economics 31, 65-76.

Blonigen, B. A. (1997) "Firm Specific Assets and the Link between Exchange Rate and Foreign Direct Investment ”, American Economic Review 87(3), 447-465.

Blonigen, B. A. (2005) “A Review of the Empirical Literature on FDI determinants”, Atlantinc Economic Journal, vol.33, pp. 383-403.

Blonigen, B. A., R.B. Davis, G.R. Waddell and H. T. Naughton (2007): "FDI spatial autoregressive relationship in foreign direct investment", European Economic Review, vil. 51, pp. 1303-1325.

Boudier-Bensebaa, F. (2005) “Agglomeration economies and location choice. Foreign Direct Investment in Hungary" Economics of Transition 13(4), 605-628. 
Caves, R. E. (1996) “Multinational Enterprise and Economic Analysis”, Second Edition, Cambridge University Press.

Chakrabarti, A. (2001) “The Determinants of Foreign Direct Investment: Sensitivity Analyses of Cross-Country Regressions”, Kyklos, Vol. 54(1), 89-114.

Combes, P. Ph, Th. Mayer and J.F. Thisse (2006): “Économie géographique. L’integration des régions et des nations", Economica.

Crozet, M., T. Mayer and J.L. Mucchielli (2004) "How do firms agglomerate? A study of FDI in France", Regional Science and Urban Economics 34, 27-54.

Culem, C. G. (1988) “The Locational Determinants of Direct Investments Among Industrialized Countries", European Economic Review 32, 885-904.

Dewhurst, J. and Ph. McCann (2007): "Sinking the iceberg ? On the treatment of transport costs in new economic geography", in B. Fingleton (Ed.) "New Directions in Economic Geography", pp. 168-203, Edward Elgar, Cheltenham, United Kingdom.

Egger, P. (2008): “On the role of distance for outward FDI”, Annals of Regional Science, vol. 42, pp. $375-389$.

European Policies Research Centre and Rheinisch-Westfalisches Institute für Wirtschaftsforschung (2000): "Impact of the Enlargement of the European Union on Small and Medium-sized Entrerprises in the Union”, University of Strathclyde Glasgow. Final Report to the European Commission- DG Entreprise.

Feenstra, R.C. (2004) Advanced International Trade. Theory and Evidence, Princeton University Press.

Feenstra, R.C. and G.H. Hanson (1997) "Foreign Direct Investment and Relative Wages: Evidence from Mexico’s Maquiladoras”, Journal of International Economics 42, 371-393. 
Fredriksson, P.G., List J.A. and Millimet, D. L. (2003): "Bureacratic corruption, environmental policy and inbound US FDI: theory and evidence", Journal of Public Economics, vol. 87, pp. 14071430.

Fujita, M., P. Krugman and A. Venables (1999): “The Spatial Economy”, the MIT Press.

Görg, H, H. Molana and C. Montagna (2009): "Foreign direct investment, tax competition and social expenditure", International Review of Economics and Finance, vol. 18, pp 31-37.

Greene, W. H. (2000) Econometric Analysis, $4^{\text {th }}$ Edition, Prentice Hall.

Hanson, G. (2001) "Should Countries Promote Foreign Direct Investment”, G-24 Discussion Papers $n^{\circ} 9$, UNCTAD, Geneva.

Harris. C. (1954): "The market as a factor in the localization of industry in the United States", Annals of the Association of American Geographers, vol.64, pp. 315-348.

Helpman, E. (1984) “A Simple Theory of International Trade with Multinational Corporations”, Journal of Political Economy 92(3), 451-471.

Head K. and Th. Mayer (2004a): "The empirics of agglomeration and trade", in J.V. Henderson and J.F. Thisse (Eds) "Handbook of Regional and Urban Economics”, Vol. 4, pp. 26092669, Elsevier North Holland.

Head K. and Th. Mayer (2004b): "Market Potential and the Location of Japanese Investment in the European Union", The Review of Economics and Statistics, vol. 86(4), pp. 959-97

Henderson, J. V. (2003) “Marshall's scale economies”, Journal of Urban Economics 53, 1-28.

Hanson, G. (2005) “Market potential, increasing returns and geographic concentration”, Journal of International Economics, 67(1), pp. 1-24.

Kravis, I.B. and R.E. Lipsey (1982) “The Location of Overseas Production and Production for Export by U.S. Multinational Firms", Journal of International Economics 12, 201-223.

Lucas, R. (1993) “On the Determinants of Direct Investment: Evidence from East and South Asia, World Development 21, 391-406. 
Markusen, J. R. (1984) “Multinationals, Multi-Plant Economies, and the Gains from Trade", Journal of International Economics 16(3-4), 205-226.

Markusen, J. R. (1997) “Trade Versus Investment Liberalization”, NBER Working Paper No. 6231.

Markusen, J. R. (2002) Multinational Firms and the Theory of International Trade, MIT Press.

McCann, Ph. (2005): “Trasport costs and new economic geography”, Journal of Economic Geography, vol. 5(3), pp. 305-318.

Redding, S. and A. Venables (2004) "Economic geography and International inequality", Journal of International Economics, vol. 62(1), pp. 53-82.

Rosenthal, S. and W. Strange (2004) "Evidence on the nature and sources of agglomeration economies", in Henderson, J.V. and J.-F. Thisse (Eds), Handbook of Regional and Urban Economics, Vol. 4, Elsevier, North Holland.

Wheeler, D and A. Mody (1992) "International Investment Location Decisions: The Case of U.S. Firms", Journal of International Economics 33, 57-76.

Wooldridge, J. M (2002) Econometric Analysis of Cross Section and Panel Data, MIT Press.

\section{Acknowledgements:}

We are grateful to Isabel Busom, Rosina Moreno for useful suggestions. This study is part of a project entitled "La situació de la innovació a Catalunya" coordinated by Isabel Busom and financed by the CIDEM. We thank the CIDEM, IDESCAT, Istituto per il Commercio Estero, Secretaría General del Comercio Exterior, Statistiches Landesamt Baden- Württemberg and Ufficio Italiano Cambi for data they provided. Any remaining error is our responsibility. Rosella Nicolini's research is supported by a Ramón y Cajal contract. Financial support from grants 2005SRG00470 and SEJ2005-01427/ECON is acknowledged. 


\section{Appendix}

[Table 11 about here]

\section{List of figures}

Figure 1 Exports as a percentage of GDP in the three regions (1995-2005)

(Sources: IDESCAT, Statistiches Landesamt Baden-Württemberg and Annuario Statistico Lombardia - Calculus: Authors)

Figure 2: Market potential of neigboring regions $(€)$

(Sources:EUROSTAT and Swiss statistics - Calculus: Authors)

Figure 3: Market potential of neigboring countries ( $\epsilon$ )

(Sources:EUROSTAT and Swiss statistics - Calculus: Authors)

Figure 4: Unit labor cost in industry

by region $(\mathbf{1 9 9 5 - 2 0 0 4 )}$

(Source EUROSTAT - Calculus: Authors)

Figure 5: Unit labor cost in services

by region (1995-2004)

(Source EUROSTAT - Calculus: Authors)

\section{List of tables}

Table 1: Fact sheet of three European regions

(Source: EUROSTAT, IDESCAT, Statistiches Landesamt Baden - Württemberg and Annuario Statistico Lombardia- Calculus: Authors)

Table 2 Cumulative FDI inflows by sector (1995-2005) (\%)

(Sources: IDESCAT, Statistiches Landesamt Baden - Württemberg and Ufficio Italiano Cambi - Calculus: Authors)

Table 3 Cumulative FDI outflows by sector (1995-2005) (\%)

(Sources: IDESCAT, Statistiches Landesamt Baden - Württemberg and Ufficio Italiano Cambi - Calculus: Authors)

Table 4 Cumulative FDI flows by country of destination or origin (1995-2005) (\%)

(Sources: IDESCAT, Statistiches Landesamt Baden - Württemberg and Ufficio Italiano Cambi - Calculus: Authors)

Box 1 : Estimation variables 
Table 5: Pooled sample

Dependent variable: FDIP

Method of estimation: LSDV (with White correction)

Values in brackets: Standard Error

Table 6: Regression by regions

Dependent variable: FDIP

Method of estimation: LSDV (with White correction and lagged regressors)

Values in brackets: Standard Error

Table 7: Regional versus national determinants (Baden Württemberg)

Dependent variable: FDIP

Method of estimation: OLS (with White correction lagged regressors)

Values in brackets: Standard Error

Table 8: Regional versus national determinants (Catalunya)

Dependent variable: FDIP

Method of estimation: OLS (with White correction lagged regressors)

Values in brackets: Standard Error

Table 9: Regional versus national determinants (Lombardia)

Dependent variable: FDIP

Method of estimation: OLS (with White correction lagged regressors)

Values in brackets: Standard Error

Table 10: The size effect of the local surrounding markets

Dependent variable: FDIP

Method of estimation: OLS (with White correction lagged regressors)

Values in brackets: Standard Error

Table 11: Composition of the surrounding regions and countries 


\section{List of figures}

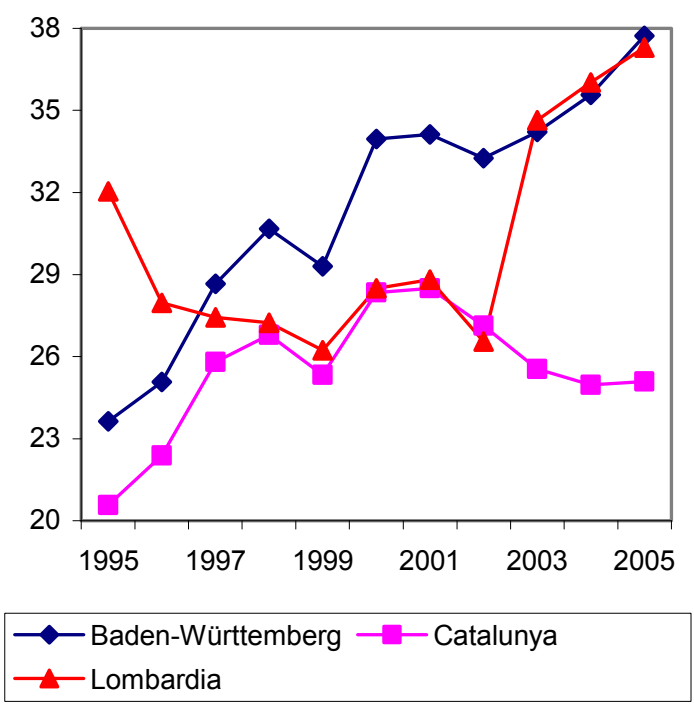

Figure 1 Exports as a percentage of GDP in the three regions (1995-2005)

(Sources: IDESCAT, Statistiches Landesamt Baden-Württemberg and Annuario Statistico Lombardia - Calculus: Authors)
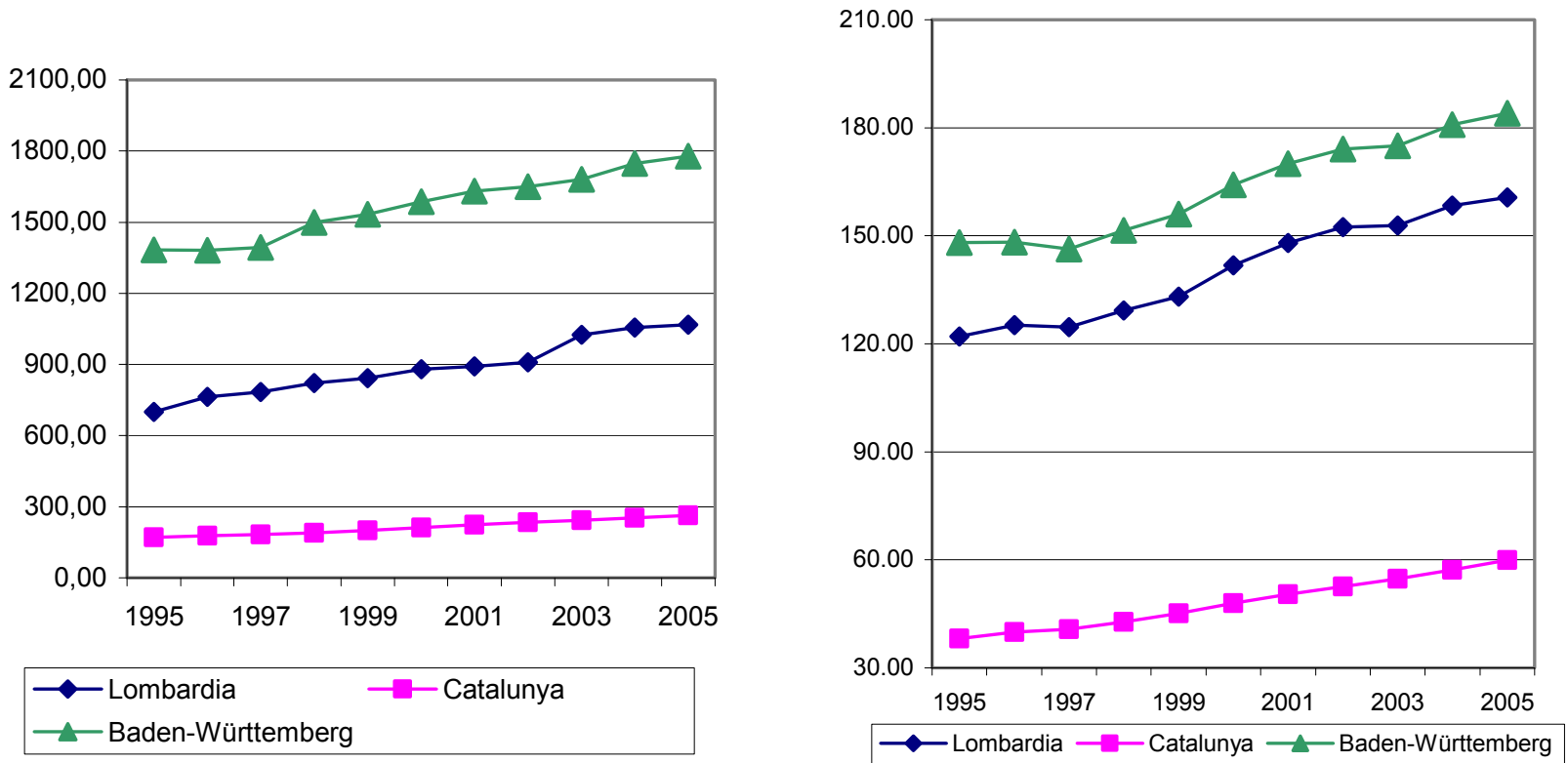

Figure 2: Market potential of neigboring regions $(€)^{23}$

Figure 3: Market potential of neigboring countries (€)

${ }^{23}$ Figures 2 and 3 are realized by using regional GDP per capita for the computation of the market potential. 


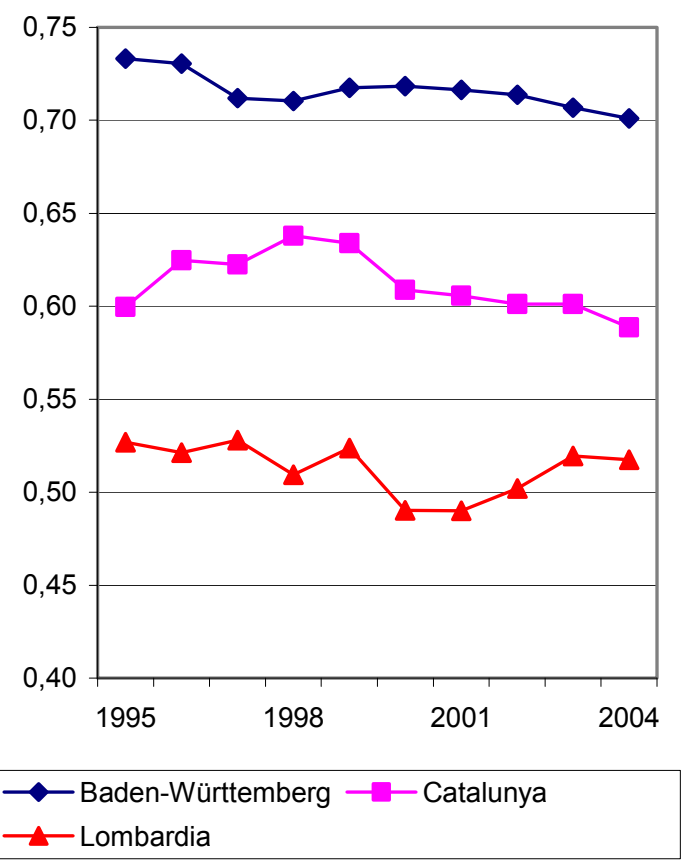

Figure 4: Unit labor cost in industry by region (1995-2004)

(Source EUROSTAT - Calculus: Authors)

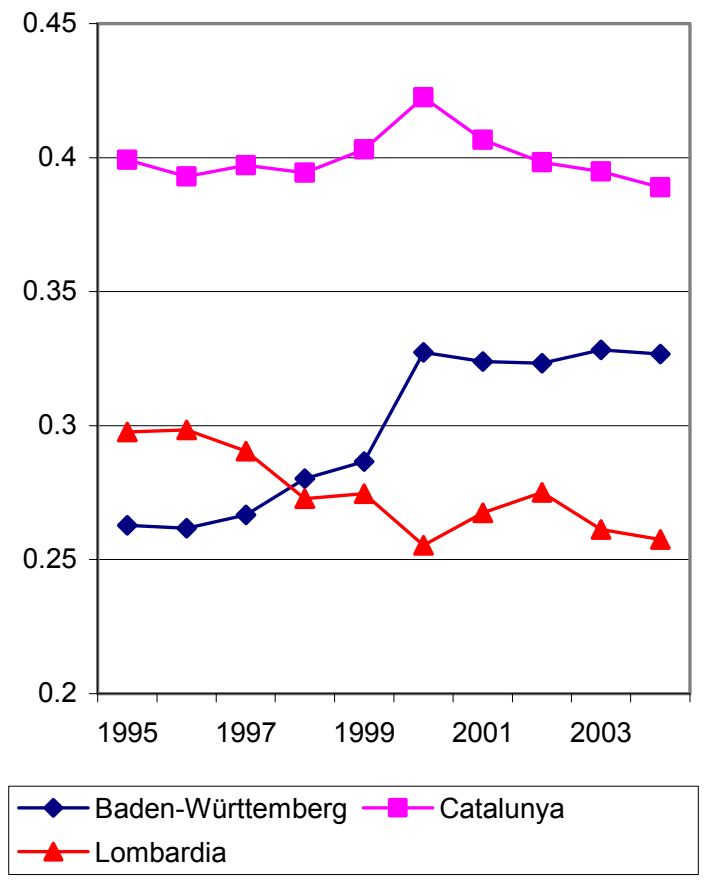

Figure 5: Unit labor cost in services by region (1995-2004)

(Source EUROSTAT - Calculus: Authors) 


\section{List of tables}

Table 1: Fact sheet of three European regions

(Source: EUROSTAT, IDESCAT, Statistiches Landesamt Baden - Württemberg and Annuario Statistico Lombardia- Calculus: Authors)

\begin{tabular}{|l|c|c|c|c|}
\hline & Population (2006) & $\begin{array}{c}\text { Area } \\
(\mathbf{s q ~ k m )}\end{array}$ & $\begin{array}{c}\text { GDP in 2005 } \\
(\boldsymbol{€} \text { millions) }\end{array}$ & $\begin{array}{c}\text { GDP per capita in } \\
\mathbf{2 0 0 5}(\boldsymbol{\epsilon})\end{array}$ \\
\hline $\begin{array}{l}\text { Catalunya } \\
\text { Waden- }\end{array}$ & 6936148 & 31930 & 170226 & 24814 \\
\hline Lombarttemberg & 10735701 & 35751 & 326417 & 30433 \\
\hline
\end{tabular}

Table 2 Cumulative FDI inflows by sector (1995-2005) (\%)

(Sources: Ministerio de Industria, Turismo y Comercio, Statistiches Landesamt Baden - Württemberg and Ufficio Italiano Cambi - Calculus: Authors)

\begin{tabular}{|l|c|c|c|}
\hline & $\begin{array}{c}\text { Baden } \\
\text { Württemberg }\end{array}$ & Catalunya & Lombardia* \\
\hline & & & \\
\hline Traditional Manufacturing & 8 & 13 & 31 \\
\hline Machinery and Automotive & 4 & 5 & 16 \\
\hline Finance and credit & 75 & 36 & 17 \\
\hline Electrical and high-tech & 2 & 11 & 9 \\
\hline Chemical & 2 & 34 & 17 \\
\hline Other services & & & 83,455 \\
\hline & 9 & 23,865 & \\
\hline TOTAL (millions $€$ ) & 494,321 & & \\
\hline
\end{tabular}

*For the period 1997-2003, ** Including Real Estates, Transport, Trade and Hotels

Table 3 Cumulative FDI outflows by sector (1995-2005) (\%)

(Sources: Ministerio de Industria, Turismo y Comercio, Statistiches Landesamt Baden - Württemberg and Ufficio Italiano Cambi - Calculus: Authors)

\begin{tabular}{|l|c|c|c|}
\hline & $\begin{array}{c}\text { Baden } \\
\text { Württemberg }\end{array}$ & Catalunya & Lombardia* \\
\hline Traditional Manufacturing & & & \\
\hline Machinery and Automotive & 11 & 28 & 35 \\
\hline Finance and credit & 16 & 5 & 3 \\
\hline Electrical and high-tech & 45 & 17 & 7 \\
\hline Chemical & 2 & 14 & 5 \\
\hline Other services & $\ldots$ & 34 & 16 \\
\hline & 26 & & 122,379 \\
\hline TOTAL (millions $€$ ) & & 38,530 & \\
\hline
\end{tabular}

* For the period 1997-2003, ** Including Real Estates, Transport, Trade and Hotels 
Table 4 Cumulative FDI flows by country of destination or origin (1995-2005) (\%)

(Sources: Ministerio de Industria, Turismo y Comercio, Statistiches Landesamt Baden - Württemberg and Ufficio Italiano Cambi - Calculus: Authors)

\begin{tabular}{|l|c|c|c|c|c|c|c|}
\hline & \multicolumn{3}{|c|}{ INFLOWS } & \multicolumn{3}{c|}{ OUTFLOWS } \\
\hline & $\begin{array}{c}\text { Baden } \\
\text { Württemberg }\end{array}$ & Catalunya & Lombardia* & $\begin{array}{c}\text { Baden } \\
\text { Württemberg }\end{array}$ & Catalunya & Lombardia* \\
\hline $\begin{array}{l}\text { European Union + } \\
\text { Switzerland }\end{array}$ & 77 & 86.3 & 87.3 & & 34.7 & 70.6 & 51.2 \\
\hline US & 12.7 & 6.6 & 9.6 & & 36.3 & 6.1 & 8.4 \\
\hline Japan & 0.7 & 1.9 & 0.9 & & $\ldots$ & 0.1 & 0.6 \\
\hline Others & 9.6 & 5.3 & 2.2 & & 29 & 23.2 & 39.8 \\
\hline & & & & & & & \\
\hline TOTAL (millions $€$ ) & 494,321 & 23,865 & 83,455 & & 700,135 & 38,530 & 122,379 \\
\hline
\end{tabular}

* For the period 1997-2003

Box 1 : Estimation variables

FDIPij : Amount of annual per-capita FDI inflows in region $i$ and sector $j$ (millions EURO)

EXPORTPi: Amount of annual per-capita export flows in region $i$ (millions EURO)

ULBVij: Unit labor cost as average compensation of employees over added value for region $i$ and sector $j$, by year GDPPi: Annual gross domestic product per-capita in region $i$ (euro)

GDPi: Annual gross domestic product in region $i$ (mill.euro)

GEXPORTP: Amount of annual per-capita export flows in Germany (millions EURO)

GULBV: Unit labor cost as average compensation of employees over added value for Germany and sector $j$, by year

IULBV: Unit labor cost as average compensation of employees over added value for Italy and sector $j$, by year

GGDPP: Annual gross domestic product per capita in Germany (euro)

GGDP: Annual gross domestic product in Germany (mill. euro)

IGDPP: Annual gross domestic product per capita in Italy (euro)

IGDP: Annual gross domestic product in Italy (mill. euro)

SGDPP: Annual gross domestic product per capita in Spain (euro)

SGDP: Annual gross domestic product per capita in Spain (mill. euro)

SULBV: Unit labor cost as average compensation of employees over added value for Spain and sector $j$, by year

DAVERAGE: (Catalunya and Baden Württemberg) Dummy for investments (by year) whose amount is greater than the average,

DUM: (Lombardia) Dummy for investments in traditional manufacturing

D2003: (Catalunya) Dummy for the 2003 year

D2004: (Catalunya) Dummy for the 2004 year

Sources:

EUROSTAT

Lombardia: Ufficio Italiano Cambi and Annuario Statistico Lombardia

Catalunya: Ministerio de Industria, Turismo y Comercio and Secretaría General del Comercio Exterior

Baden Württemberg: Statistiches Landesamt Baden- Württemberg 
Table 5: Pooled sample

Dependent variable: FDIP

Method of estimation: LSDV (with White correction and lagged regressors)

Values in brackets: Standard Error

\begin{tabular}{|l|c|c|c|c|}
\hline & 1 & 2 & 3 & 4 \\
\hline C & $\begin{array}{c}0.38^{* *} \\
(0.19)\end{array}$ & $\begin{array}{c}1.62^{* * *} \\
(0.39)\end{array}$ & $\begin{array}{c}0.89^{* *} \\
(0.40)\end{array}$ & $\begin{array}{c}1.023^{* * *} \\
(0.30)\end{array}$ \\
\hline ULBV & $\begin{array}{c}-1.64^{* * *} \\
(0.63)\end{array}$ & $\begin{array}{c}-3.63^{* * *} \\
(0.84)\end{array}$ & $\begin{array}{c}-3.62^{* * *} \\
(0.82)\end{array}$ & $\begin{array}{c}-3.63^{* * *} \\
(0.82)\end{array}$ \\
\hline GDPP & $\begin{array}{c}0.03^{* * *} \\
(0.01)\end{array}$ & & $\begin{array}{c}0.03^{*} \\
(0.015)\end{array}$ & \\
\hline EXPORTP & & & & $\begin{array}{c}0.07^{* *} \\
(0.03)\end{array}$ \\
\hline & & & & \\
\hline $\begin{array}{l}\text { Fixed effects } \\
\text { by region }\end{array}$ & No & Yes & Yes & Yes \\
\hline F-test & & $125.80^{* * *}$ & $101.65^{* * *}$ & $113.33^{* * *}$ \\
\hline $\begin{array}{l}\text { Adj R- } \\
\text { squared }\end{array}$ & 0.13 & 0.48 & 0.49 & 0.50 \\
\hline N. Obs & 150 & 150 & 150 & 150 \\
\hline
\end{tabular}

$* * *$ Level of significance $1 \%, * * 5 \%$. $* 10 \%$ 

Table 6: Regressions by region

Dependent variable: FDIP

Method of estimation: LSDV (with White correction and lagged regressors)

Values in brackets: Standard Error

\begin{tabular}{|c|c|c|c|c|c|c|c|c|c|}
\hline & \multicolumn{3}{|c|}{ Baden Württemberg $^{24}$} & \multicolumn{3}{|c|}{ Catalunya } & \multicolumn{3}{|c|}{ Lombardia } \\
\hline & 1 & 2 & 3 & 1 & 2 & 3 & 1 & 2 & 3 \\
\hline C & $\begin{array}{c}0.54 * * * \\
(0.14)\end{array}$ & $\begin{array}{c}-6.52 * * * \\
(1.67)\end{array}$ & $\begin{array}{c}-1.40 * * * \\
(0.49)\end{array}$ & $\begin{array}{c}-0.16^{* *} \\
(0.07)\end{array}$ & $\begin{array}{c}-0.13 \\
(0.08)\end{array}$ & $\begin{array}{c}0.03 \\
(0.06)\end{array}$ & $\begin{array}{c}0.03^{* * *} \\
(0.08)\end{array}$ & $\begin{array}{c}-0.08^{* *} \\
(0.03)\end{array}$ & $\begin{array}{l}-0.02 \\
(0.02)\end{array}$ \\
\hline DAVERAGE & $\begin{array}{c}3.27 * * * \\
(0.50)\end{array}$ & $\begin{array}{c}3.34 * * * \\
(0.33)\end{array}$ & $\begin{array}{c}3.32 * * * \\
(0.34)\end{array}$ & $\begin{array}{c}0.08 * * * \\
(0.02)\end{array}$ & $\begin{array}{c}0.09^{* * *} \\
(0.02)\end{array}$ & $\begin{array}{c}0.09 * * * \\
(0.02)\end{array}$ & & & \\
\hline DUM & & & & & & & $\begin{array}{c}0.02 * \\
(0.009)\end{array}$ & $\begin{array}{l}0.02 * * \\
(0.007)\end{array}$ & $\begin{array}{c}0.017 * * \\
(0.007)\end{array}$ \\
\hline ULBV & $\begin{array}{c}-0.73 * * \\
(0.33)\end{array}$ & $\begin{array}{c}-2.01 * * * \\
(0.50)\end{array}$ & $\begin{array}{c}-1.79 * * * \\
(0.49)\end{array}$ & $\begin{array}{c}-0.25^{* *} \\
(0.12)\end{array}$ & $\begin{array}{c}-0.21 * * \\
(0.10)\end{array}$ & $\begin{array}{c}-0.21 * * \\
(0.09)\end{array}$ & $\begin{array}{l}-0.03^{*} \\
(0.02)\end{array}$ & $\begin{array}{c}-0.02^{*} \\
(0.012)\end{array}$ & $\begin{array}{c}-0.03^{*} \\
(0.014)\end{array}$ \\
\hline GDPP & & $\begin{array}{c}0.28 * * * \\
(0.07)\end{array}$ & & & $\begin{array}{c}0.02 * * * \\
(0.005)\end{array}$ & & & $\begin{array}{c}0.004 * * * \\
(0.013)\end{array}$ & \\
\hline EXPORTP & & & $\begin{array}{c}0.27 * * * \\
(0.08)\end{array}$ & & & $\begin{array}{c}4.54 \mathrm{E}-09^{* * * *} \\
(1.43 \mathrm{E}-09)\end{array}$ & & & $\begin{array}{c}-0.005^{* *} \\
(0.002)\end{array}$ \\
\hline D2003 & & & & & $\begin{array}{c}-0.14 * * * \\
(0.04)\end{array}$ & $\begin{array}{c}-0.12 * * * \\
(0.03)\end{array}$ & & & \\
\hline D2004 & & & & & $\begin{array}{c}-0.15^{* * * *} \\
(0.05) \\
\end{array}$ & $\begin{array}{c}-0.09^{* *} \\
(0.03) \\
\end{array}$ & & & \\
\hline $\begin{array}{l}\text { Adj R- } \\
\text { squared }\end{array}$ & 0.78 & 0.86 & 0.85 & 0.33 & 0.46 & 0.44 & 0.14 & 0.42 & 0.32 \\
\hline N. Obs & 60 & 60 & 60 & 54 & 54 & 54 & 36 & 36 & 36 \\
\hline
\end{tabular}

$* * *$ Level of significance $1 \%, * * 5 \%, * 10 \%$

${ }^{24}$ Statistics by The Statistiches Landesamt of Baden-Württemberg allow to build series for regressors since 1994. As a result, we can keep the number of observations fixed at 60 . 
Table 7: Regional versus national determinants

Dependent variable: FDIP

Method of estimation: OLS (with White correction and lagged regressors)

Values in brackets: Standard Error

\begin{tabular}{|c|c|c|c|c|c|c|}
\hline & & (1) & (2) & (3) & (4) & (5) \\
\hline \multirow{10}{*}{ 1: } & $\mathrm{C}$ & $\begin{array}{c}-6.52 * * * \\
(1.67)\end{array}$ & $\begin{array}{c}-8.08 * * * \\
(1.95)\end{array}$ & $\begin{array}{c}-6.47 * * \\
(1.92)\end{array}$ & $\begin{array}{c}-4.36 * * * \\
(1.16)\end{array}$ & $\begin{array}{c}-4.88^{* * * *} \\
(1.21)\end{array}$ \\
\hline & DAVARAGE & $\begin{array}{c}3.34 * * * \\
(0.33)\end{array}$ & $\begin{array}{c}3.34 * * * \\
(0.33)\end{array}$ & $\begin{array}{c}2.97^{* * * *} \\
(0.39)\end{array}$ & $\begin{array}{c}3.34 * * * \\
(0.32)\end{array}$ & $\begin{array}{c}3.34 * * * * \\
(0.33)\end{array}$ \\
\hline & ULBV & $\begin{array}{c}-2.01 * * * \\
(0.50)\end{array}$ & $\begin{array}{c}-2.74 * * * \\
(0.49)\end{array}$ & & $\begin{array}{c}-1.99 * * * \\
(0.49)\end{array}$ & $\begin{array}{c}-2.12^{* * * *} \\
(0.50)\end{array}$ \\
\hline & GDPP & $\begin{array}{c}0.28 * * * \\
(0.07)\end{array}$ & & $\begin{array}{c}0.27^{* * * *} \\
(0.08)\end{array}$ & & \\
\hline & GGDPP & & $\begin{array}{c}0.0004 * * * \\
(8.64 \text { E-05) } \\
\end{array}$ & & & \\
\hline & GULBV & & & $\begin{array}{c}-1.69 * * * \\
(0.39)\end{array}$ & & \\
\hline & $\begin{array}{l}\text { Market potential } \\
\text { (by region) with } \\
\text { GDP per capita }\end{array}$ & & & & $\begin{array}{c}0.003 * * * \\
(0.0008)\end{array}$ & \\
\hline & $\begin{array}{l}\text { Market potential } \\
\text { (by country) with } \\
\text { GDP per capita }\end{array}$ & & & & & $\begin{array}{c}0.037^{* * *} \\
(0.008)\end{array}$ \\
\hline & Adj. R-square & 0.86 & 0.86 & 0.83 & 0.86 & 0.86 \\
\hline & Obs & 60 & 60 & 60 & 60 & 60 \\
\hline
\end{tabular}

Level of significance: $* * * 1 \%, * * 5 \%$. $* 10 \%$

Table 8: Regional versus national determinants

Dependent variable: FDIP

Method of estimation: OLS (with White correction lagged regressors)

Values in brackets: Standard Error

\begin{tabular}{|c|c|c|c|c|c|c|}
\hline & & (1) & (2) & (3) & (4) & (5) \\
\hline \multirow{12}{*}{ 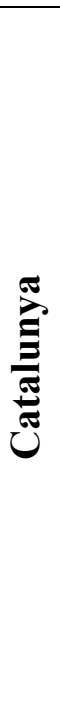 } & C & $\begin{array}{l}-0.13 \\
(0.08)\end{array}$ & $\begin{array}{c}-0.09 \\
(0.08) \\
\end{array}$ & $\begin{array}{l}-0.10 \\
(0.09)\end{array}$ & $\begin{array}{l}-0.17^{*} \\
(0.10)\end{array}$ & $\begin{array}{l}-0.16^{*} \\
(0.09)\end{array}$ \\
\hline & DAVARAGE & $\begin{array}{c}0.09 * * * \\
(0.02) \\
\end{array}$ & $\begin{array}{c}0.09 * * * \\
(0.02)\end{array}$ & $\begin{array}{c}0.09^{* * * *} \\
(0.02)\end{array}$ & $\begin{array}{c}0.09 * * * \\
(0.02) \\
\end{array}$ & $\begin{array}{c}0.09 * * * \\
(0.02)\end{array}$ \\
\hline & ULBV & $\begin{array}{c}-0.21^{* *} \\
(0.10)\end{array}$ & $\begin{array}{c}-0.21^{* *} \\
(0.10)\end{array}$ & & $\begin{array}{c}-0.21^{* *} \\
(0.10) \\
\end{array}$ & $\begin{array}{c}-0.21^{* * *} \\
(0.10)\end{array}$ \\
\hline & GDPP & $\begin{array}{c}0.017^{* * *} \\
(0.005)\end{array}$ & & $\begin{array}{c}0.017^{* * *} \\
(0.005)\end{array}$ & & \\
\hline & SGDPP & & $\begin{array}{c}1.77 \mathrm{E}-05^{* * *} \\
(5.63 \mathrm{E}-06)\end{array}$ & & & \\
\hline & SULBV & & & $\begin{array}{c}-0.25^{* *} \\
(0.12) \\
\end{array}$ & & \\
\hline & D2003 & $\begin{array}{c}-0.14^{* * * *} \\
(0.04) \\
\end{array}$ & $\begin{array}{c}-0.14^{* * * *} \\
(0.04) \\
\end{array}$ & $\begin{array}{c}-0.09^{* *} \\
(0.04) \\
\end{array}$ & $\begin{array}{c}-0.13 * * * \\
(0.04) \\
\end{array}$ & $\begin{array}{c}-0.13^{* * * *} \\
(0.04)\end{array}$ \\
\hline & D2004 & $\begin{array}{c}-0.15^{* * * *} \\
(0.05) \\
\end{array}$ & $\begin{array}{c}-0.13^{* * * *} \\
(0.04) \\
\end{array}$ & $-0.07^{*}$ & $\begin{array}{c}-0.13^{* * * *} \\
(0.04) \\
\end{array}$ & $\begin{array}{c}-13^{* * * *} \\
(0.04) \\
\end{array}$ \\
\hline & $\begin{array}{l}\text { Market potential } \\
\text { (by region) with } \\
\text { GDP per capita }\end{array}$ & & & & $\begin{array}{l}0.002 * * * \\
(0.0005)\end{array}$ & \\
\hline & $\begin{array}{l}\text { Market potential } \\
\text { (by country) with } \\
\text { GDP per capita } \\
\end{array}$ & & & & & $\begin{array}{c}0.007 * * * \\
(0.002)\end{array}$ \\
\hline & Adj. R-square & 0.46 & 0.45 & 0.47 & 0.44 & 0.45 \\
\hline & Obs & 54 & 54 & 54 & 54 & 54 \\
\hline
\end{tabular}

Level of significance: $* * * 1 \%, * * 5 \%$. $* 10 \%$ 
Table 9: Regional versus national determinants

Dependent variable: FDIP

Method of estimation: OLS (with White correction and lagged regressors)

Values in brackets: Standard Error

\begin{tabular}{|c|c|c|c|c|c|c|}
\hline & & (1) & (2) & (3) & (4) & (5) \\
\hline \multirow{10}{*}{ 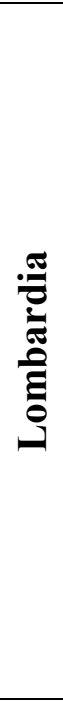 } & $\mathrm{C}$ & $\begin{array}{c}-0.08^{* *} \\
(0.03)\end{array}$ & $\begin{array}{c}-0.10^{* * * *} \\
(0.031)\end{array}$ & $\begin{array}{c}-0.09 * * * \\
(0.032)\end{array}$ & $\begin{array}{c}-0.07 * * \\
(0.04)\end{array}$ & $\begin{array}{c}-0.11 * * * \\
(0.032)\end{array}$ \\
\hline & DUM & $\begin{array}{l}0.17 * * \\
(0.07)\end{array}$ & $\begin{array}{l}0.02 * * \\
(0.07)\end{array}$ & $\begin{array}{c}0.015 * * \\
(0.007) \\
\end{array}$ & $\begin{array}{l}0.017^{* *} \\
(0.007)\end{array}$ & $\begin{array}{c}0.017 * * \\
(0.007) \\
\end{array}$ \\
\hline & ULBV & $\begin{array}{l}-0.02 * \\
(0.01) \\
\end{array}$ & $\begin{array}{c}-0.02 * * \\
(0.01) \\
\end{array}$ & & $\begin{array}{l}-0.02 * \\
(0.01)\end{array}$ & $\begin{array}{c}-0.02 * * \\
(0.01) \\
\end{array}$ \\
\hline & GDPP & $\begin{array}{c}0.004 * * * \\
(0.001)\end{array}$ & & $\begin{array}{c}0.004 * * * \\
(0.001)\end{array}$ & & \\
\hline & IGDPP & & $\begin{array}{c}5.78 \mathrm{E}-06^{* * *} \\
(1.43 \mathrm{E}-06)\end{array}$ & & & \\
\hline & IULBV & & & $\begin{array}{c}-0.00003 \\
(0.015) \\
\end{array}$ & & \\
\hline & $\begin{array}{l}\text { Market potential } \\
\text { (by region) with } \\
\text { GDP per capita }\end{array}$ & & & & $\begin{array}{c}0.0001^{* *} \\
(4.00 \mathrm{E}-05)\end{array}$ & \\
\hline & $\begin{array}{l}\text { Market potential } \\
\text { (by country) with } \\
\text { GDP per capita } \\
\end{array}$ & & & & & $\begin{array}{c}0.0009^{* *} \\
(0.0002)\end{array}$ \\
\hline & Adj. R-square & 0.42 & 0.45 & 0.38 & 0.34 & 0.44 \\
\hline & Obs & 36 & 36 & 36 & 36 & 36 \\
\hline
\end{tabular}

Level of significance: $* * * 1 \%, * * 5 \%, * 10$ 
Table 10: The size effect of the local surrounding markets

Dependent variable: FDIP

Method of estimation: OLS (with White correction lagged regressors)

Values in brackets: Standard Error

\begin{tabular}{|c|c|c|c|c|c|}
\hline & & (1) & (2) & (3) & (4) \\
\hline \multirow{9}{*}{ | } & $\mathrm{C}$ & $\begin{array}{c}-6.11 * * * \\
(1.55)\end{array}$ & $\begin{array}{c}-7.65^{* * * *} \\
(1.84)\end{array}$ & $\begin{array}{c}-5.24 * * * \\
(1.27)\end{array}$ & $\begin{array}{c}-4.19 * * * \\
(1.19)\end{array}$ \\
\hline & DAVARAGE & $\begin{array}{c}3.34 * * * \\
(0.33)\end{array}$ & $\begin{array}{c}3.34 * * * \\
(0.33)\end{array}$ & $\begin{array}{c}3.35^{* * * *} \\
(0.32) \\
\end{array}$ & $\begin{array}{c}3.35^{* * *} \\
(0.32) \\
\end{array}$ \\
\hline & ULBV & $\begin{array}{c}-2.04 * * * \\
(0.50)\end{array}$ & $\begin{array}{c}-2.10^{* * * *} \\
(0.49)\end{array}$ & $\begin{array}{c}-2.14 * * * \\
(0.50)\end{array}$ & $\begin{array}{c}-2.17 * * * \\
(0.50)\end{array}$ \\
\hline & GDP & $\begin{array}{c}2.47 \mathrm{E}-05^{* * * *} \\
(5.97 \mathrm{E}-06) \\
\end{array}$ & & & \\
\hline & GGDP & & $\begin{array}{c}4.31 \mathrm{E}-06^{* * * *} \\
(9.97 \mathrm{E}-07)\end{array}$ & & \\
\hline & $\begin{array}{l}\text { Market potential } \\
\text { (by region) with } \\
\text { total GDP }\end{array}$ & & & $\begin{array}{l}0.002 * * * \\
(0.0004)\end{array}$ & \\
\hline & $\begin{array}{l}\text { Market potential } \\
\text { (by country) with } \\
\text { total GDP }\end{array}$ & & & & $\begin{array}{l}0.001 * * * \\
(0.0002)\end{array}$ \\
\hline & Adj. R-square & 0.86 & 0.86 & 0.87 & 0.87 \\
\hline & Obs & 60 & 60 & 60 & 60 \\
\hline \multirow{11}{*}{ 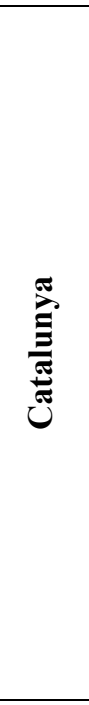 } & $\mathrm{C}$ & $\begin{array}{l}-0.07 \\
(0.07)\end{array}$ & $\begin{array}{l}-0.07 \\
(0.07)\end{array}$ & $\begin{array}{l}-0.12 \\
(0.08)\end{array}$ & $\begin{array}{l}-0.14 \\
(0.09)\end{array}$ \\
\hline & DAVARAGE & $\begin{array}{c}0.09^{* * *} \\
(0.02) \\
\end{array}$ & $\begin{array}{c}0.09^{* * *} \\
(0.02) \\
\end{array}$ & $\begin{array}{c}0.09^{* * *} \\
(0.02) \\
\end{array}$ & $\begin{array}{c}0.09^{* * *} \\
(0.02) \\
\end{array}$ \\
\hline & ULBV & $\begin{array}{c}-0.21^{* *} \\
(0.10)\end{array}$ & $\begin{array}{c}-0.21^{* *} \\
(0.10)\end{array}$ & $\begin{array}{c}-0.21 * * \\
(0.10)\end{array}$ & $\begin{array}{c}-0.21^{* *} \\
(0.10)\end{array}$ \\
\hline & GDP & $\begin{array}{c}2.16 \mathrm{E}-06^{* * *} \\
(6.87 \mathrm{E}-07)\end{array}$ & & & \\
\hline & SGDP & & $\begin{array}{c}4.01 \mathrm{E}-07 * * * \\
(9.23 \mathrm{E}-06) \\
\end{array}$ & & \\
\hline & D2003 & $\begin{array}{c}-0.14 * * * \\
(0.04)\end{array}$ & $\begin{array}{l}-0.14 * * * \\
(0.038)\end{array}$ & $\begin{array}{c}-0.14 * * * \\
(0.04)\end{array}$ & $\begin{array}{c}-0.14 * * * \\
(0.04)\end{array}$ \\
\hline & D2004 & $\begin{array}{c}-0.14 * * * \\
(0.04)\end{array}$ & $\begin{array}{c}-0.14 * * * \\
(0.043)\end{array}$ & $\begin{array}{c}-0.13 * * * \\
(0.04)\end{array}$ & $\begin{array}{c}-0.13 * * * \\
(0.04)\end{array}$ \\
\hline & $\begin{array}{l}\text { Market potential } \\
\text { (by region) with } \\
\text { total GDP }\end{array}$ & & & $\begin{array}{c}0.0006^{* * * *} \\
(0.0001)\end{array}$ & \\
\hline & $\begin{array}{l}\text { Market potential } \\
\text { (by country) with } \\
\text { total GDP }\end{array}$ & & & & $\begin{array}{l}0.0001^{* * *} \\
(4.40 \mathrm{E}-05)\end{array}$ \\
\hline & Adj. R-square & 0.42 & 0.45 & 0.45 & 0.45 \\
\hline & Obs & 54 & 54 & 54 & 54 \\
\hline \multirow{9}{*}{ 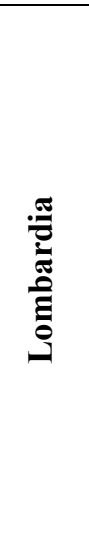 } & $\mathbf{C}$ & $\begin{array}{c}-0.08^{* * * *} \\
(0.03) \\
\end{array}$ & $\begin{array}{c}-0.09^{* * * *} \\
(0.03) \\
\end{array}$ & $\begin{array}{c}-0.11^{* * * *} \\
(0.03) \\
\end{array}$ & $\begin{array}{c}-0.09^{* * *} \\
(0.03) \\
\end{array}$ \\
\hline & DUM & $\begin{array}{l}0.02^{* * *} \\
(0.007)\end{array}$ & $\begin{array}{l}0.02 * * \\
(0.007)\end{array}$ & $\begin{array}{l}0.02 * * \\
(0.007)\end{array}$ & $\begin{array}{l}0.02 * * \\
(0.007)\end{array}$ \\
\hline & ULBV & $\begin{array}{c}-0.02^{* *} \\
(0.01) \\
\end{array}$ & $\begin{array}{l}-0.02^{*} \\
(0.01) \\
\end{array}$ & $\begin{array}{l}-0.02^{*} \\
(0.01) \\
\end{array}$ & $\begin{array}{c}-0.02^{* *} \\
(0.01)\end{array}$ \\
\hline & GDP & $\begin{array}{c}4.00 \mathrm{E}-07 * * * \\
(1.01 \mathrm{E}-07) \\
\end{array}$ & & & \\
\hline & IGDP & & $\begin{array}{c}9.62 \mathrm{E}-08^{* * * *} \\
(2.43 \mathrm{E}-08)\end{array}$ & & \\
\hline & $\begin{array}{l}\text { Market potential } \\
\text { (by region) with } \\
\text { total GDP }\end{array}$ & & & $\begin{array}{c}6.31 \mathrm{E}-05^{* * *} \\
(1.62 \mathrm{E}-05)\end{array}$ & \\
\hline & $\begin{array}{l}\text { Market potential } \\
\text { (by country) with } \\
\text { total GDP }\end{array}$ & & & & $\begin{array}{c}4.09 \mathrm{E}-05^{* * * *} \\
(1.01 \mathrm{E}-05)\end{array}$ \\
\hline & Adj. R-square & 0.45 & 0.45 & 0.44 & 0.45 \\
\hline & Obs & 36 & 36 & 36 & 36 \\
\hline
\end{tabular}

Level of significance: $* * * 1 \%, * * 5 \%$. $* 10$ 
Table 11: Composition of the surrounding regions and countries

\begin{tabular}{|c|c|c|}
\hline & By region & By country \\
\hline \multirow[t]{3}{*}{ Baden Württemberg } & $\begin{array}{l}\text { Switzerland: Bâle ville, } \\
\text { Bâle campagne, Argovie, } \\
\text { Zürich, Schaffhousen, } \\
\text { Turgovie, Sant Gall }\end{array}$ & \multirow[t]{3}{*}{$\begin{array}{l}\text { France, Germany, } \\
\text { Switzerland }\end{array}$} \\
\hline & France: Alsace & \\
\hline & $\begin{array}{l}\text { Germany: Bayern, } \\
\text { Hassen, Rheinland-Pfalz }\end{array}$ & \\
\hline \multirow[t]{2}{*}{ Catalunya } & $\begin{array}{l}\text { France: Midi-Pyrénées, } \\
\text { Languedoc-Roussillon }\end{array}$ & \multirow[t]{2}{*}{ France, Spain } \\
\hline & $\begin{array}{l}\text { Spain: Aragón, } \\
\text { Comunidad Valenciana }\end{array}$ & \\
\hline \multirow[t]{2}{*}{ Lombardia } & $\begin{array}{l}\text { Italy: Emilia Romagna, } \\
\text { Piemonte, Prov. Auton. Di } \\
\text { Trento, Veneto, }\end{array}$ & \multirow[t]{2}{*}{ Italy, Switzerland } \\
\hline & $\begin{array}{l}\text { Switzerland: Canton } \\
\text { Ticino }\end{array}$ & \\
\hline
\end{tabular}

